\author{
Available online at http://bajas.edu.iq \\ https://doi.org/10.37077/25200860.2019.264 \\ College of Agriculture, University of Basrah
}

\section{Basrah Journal of Agricultural Sciences}

ISSN $1814-5868$

Basrah J. Agric. Sci., 32 (Spec. Issue 2): 140-155, 2019

E-ISSN: 2520-0860

\title{
Evaluation of some Herbicides' Efficacy in Weed Control Accompanying some Wheat Cultivars and Their Effect on Yield and Its Components
}

\author{
Sura A. Khudur*, Taha Y.M. Al-Edany \& Layla A. Bnayan \\ Department of Plant Protection, College of Agricultural, University of Basrah, Iraq \\ *Corresponding author e-mail: sura-aledany@gmail.com \\ Received 19 September 2019; Accepted 18 November 2019; Available online 22 November 2019
}

\begin{abstract}
A field experiment was conducted at Al-Qaim area $90 \mathrm{~km}$ north of Basrah Province, Iraq during the growing season of 2018-2019. The purpose of this study was to evaluate the efficacy of three different herbicides includes Pallas 4.5\%OD (125ml.Donum ${ }^{-}$ ${ }^{2}$ ), Spotlight75\%DWG(5g.Donum ${ }^{-2}$ ) and Clodex100EC (150ml.Donum ${ }^{-2}$ ) to control the weeds growing with two cultivars of wheat (Ebaa-99 and Buhooth-22). The results showed that Ebaa-99 cultivar was superior in the average of plant height $(77.99 \mathrm{~cm})$, flag leaf area $\left(29.15 \mathrm{~cm}^{2}\right)$, number of tillers $\left(701.50\right.$ tillers. $\left.\mathrm{m}^{-2}\right)$, number of spikes $\left(615.61\right.$ spikes. $\left.\mathrm{m}^{-2}\right)$, weight of 1000 grain $(43.41 \mathrm{~g})$, grain yield (5203.34 Kg.ton $\left.{ }^{-2}\right)$, biological yield (15216.58 $\mathrm{Kg} / \mathrm{ha}$ ), harvest indicator $(35.25 \%)$, dry weight of narrow-leaved $\left(14.14 \mathrm{~g} . \mathrm{m}^{-2}\right)$ and broadleaved weeds $\left(43.64 \mathrm{~g} . \mathrm{m}^{-2}\right)$. While Buhooth-22 cultivar revealed superiority in the number of grains per spike $\left(28.66\right.$ grain.spike $\left.{ }^{-2}\right)$, length of the spike $(7.76 \mathrm{~cm})$ and protein content $(10.47 \%)$. Spraying treatments by the formulation of the herbicides Spotlight and Clodex were significantly exceeded other treatments in all crop plant growing components.
\end{abstract}

Key words: Herbicides, Wheat Cultivars, Weeds.

\section{Introduction}

Wheat (Triticum aestivum L.) is considered as one of the most important and strategic crops of the world. It is the main source of food and has an essential role in the economic development, followed by rice and corn (Shewry et al., 2002). In spite of its importance in Iraq, the rate of yield per unit area is very low in comparison with the average world yield. FAOSTAT stated that the production of wheat is more than 700 million metric tons around the world. In 2016, the world wheat production was 749.5 million tons, and the production concentrated in China, the United States, India, and Russia, while it was only 3.1 million tons in Iraq (FAO, 2016). The obvious reason for low production is the growth of different weeds in the wheat fields, which compete the crop for nutrients, light and other growing requirements leading to a drop in the yield qualitative and quantitive. Many studies mentioned that this competition decreases the wheat production within 13$43 \%$ depending on the species and density of weeds. Al-Jubury (2002) classified the weeds associated with the wheat crop as 12 species of narrow-leaved and 16 species of broad-leaved weeds. Weeds are one of the limiting factors for agricultural production because of their competition with crops on essential growth elements including light, water, and nutrients 
(Öztürk et al., 2012). The weeds injury on the wheat crops exceeds any other agricultural pest (Al-Hassawy \& AlJubury, 1982). Therefore, controlling weeds is one of the most effective means of enhancing wheat yield. The chemical herbicide is widely used to decrease the risk of weed pervasiveness (Steven et al., 2010). The efficiency of chemical herbicides depends on several factors to achieve the highest activity for controlling the growth of the weed such as the type and efficiency of herbicides, soil, and climatic circumstances during herbicides spray. (Razzak, 2017).

The current research planned to study the response of some local wheat cultivars in Basrah to the use of common herbicides of weeds.

Materials \& Methods
This experiment was applied in a privet field at Al-Qaim area, $90 \mathrm{~km}$ to the north of Basrah at $30^{\circ} .22^{\prime} \mathrm{N}$ and $47^{\circ} .42^{\prime} \mathrm{E}$ to evaluate the efficacy of chemical control of weeds on some growth and yield components of two wheat cultivars, Ebaa99 and Buhooth -22 during the growing season 2018-2019.

The experiment was applied by RCBD design as split plot arrangement with three replicates and means were separated using Least Significant difference (L.S.D.) test at $\mathrm{p}<0.05$ (Al-Rawi \& Khalaf-Allah, 1980). Main plots are held the four treatments of chemical control including herbicides Pallas 4.5\%OD, Spotlight $75 \%$ DW, Clodex 100EC (Table 1), control, and hand weeding. While cultivars Ebaa99 and Buhooth-22 planted prose in the secondary plots. Before cultivation, random soil samples were taken down to $30 \mathrm{~cm}$ deep and

Table (1): Treatments herbicides used in the experiment.

\begin{tabular}{|c|c|c|c|}
\hline Herbicides & Common names & Dose & Type of weeds targeting \\
\hline $\begin{array}{l}\text { Pallas } \\
\% \mathrm{OD}\end{array}$ & Pyroxsulam & 125 ml.Donum ${ }^{-1}$ & $\begin{array}{l}\text { Broadleaved Weeds \& } \\
\text { narrow leaved weeds }\end{array}$ \\
\hline $\begin{array}{l}\text { Spotlight75 \% } \\
\text { DW }\end{array}$ & $\begin{array}{l}\text { Tribenuron }- \text { Methyl } \\
75 \%\end{array}$ & 5 g.Donum ${ }^{-1}$ & Broadleaved Weeds \\
\hline Clodex 100EC & $\begin{array}{l}\text { Cloquintocetmexyl+ } \\
\text { Clodinafop-Propargyl }\end{array}$ & 150 ml.Donum $^{-1}$ & narrow leaved weeds \\
\hline
\end{tabular}

Table (2): Physical and chemical characteristics of the soil during season 2018/2019.

\begin{tabular}{|c|c|c|c|}
\hline Soil separa & ates & Texture & Unitbroadcastprose \\
\hline \%Clay & 17 & \multirow{3}{*}{ Silt } & \multirow{3}{*}{ g. $100 \mathrm{~g}^{-1}$} \\
\hline$\%$ Silt & 79 & & \\
\hline$\%$ sand & 4 & & \\
\hline $\mathrm{pH}$ & & 7.3 & \\
\hline $\mathrm{EC}$ & & 3.85 & $\mathrm{dsm}^{-1}$ \\
\hline Available nitrogen & & 0.20 & g. $\mathrm{kg}^{-1}$ \\
\hline Available phosphorus & & 0.022 & g. $\mathrm{kg}^{-1}$ \\
\hline Available potassium & & 0.25 & g. $\mathrm{kg}^{-1}$ \\
\hline
\end{tabular}

analyzed to determine the physical and chemical characteristics. The analysis was carried out at the Central Laboratory, College of Agriculture, University of 
Basrah. The results were summarized in table (2).

The land was plowed two times and divided into experimental units of 250 $\mathrm{m}^{2}(10 \times 25 \mathrm{~m})$. The space between units and replicates was $50 \mathrm{~cm}$. Two cultivars of wheat were cultivated in $5 / 11 / 2018$ at the rate of sowing $120 \mathrm{Kg} \cdot \mathrm{ha}^{-1}$, added fertilizer at the rate $75 \mathrm{Kg} \mathrm{ha}^{-1}$ of triple superphosphate $\left(\mathrm{P}_{2} \mathrm{O}_{5}, 47 \%\right)$ was added before seeding while nitrogen fertilizer was added at the rate of $138 \mathrm{Kg}^{-h^{-1}}$ as urea $(\mathrm{N}$, $46 \%$ ) in two batches. The First one was at the branching stage and the second was at the booting stage (Jadooa, 2012). Herbicides were sprayed on 28/12/2018 when wheat

\section{Percentage inhibition.}

This percentage is counted from the formula mentioned in Ciba-Geigy (1975).

$$
\text { Inhibition percent }=100-\left(100 \times \frac{\mathrm{A}}{\mathrm{B}}\right) \text {. }
$$

$A=$ Dry weight of weeds in herbicide treatment. $\mathrm{B}=$ Dry weight of weeds in control treatment

\section{Plant height (cm)}

The height of ten plants from each experimental unit was measured by a graduated ruler from soil level up to the base of the spike in the main stalk at plants were at the end of tillering and the beginning of the elongation stage and weeds were at the 3-4 leaf stage. Harvest the crop using the square meter on $15 / 4 / 2019$. The following characteristics were studied:

\section{The dry weight of weeds $\left(\mathrm{g} \cdot \mathrm{m}^{-2}\right)$}

Weeds were cut from the soil level within the area of $50 * 50 \mathrm{~cm}$, and they were kept in polyethylene sacs, then dried in the lab using the electric oven at $70{ }^{\circ} \mathrm{C}$ for $72 \mathrm{hrs}$ until the stability of the weight. Narrowleaved and broad-leaved weeds were separated. Samples were weighed by sensitive electric balance as mentioned by Al-Chalabi (1988).

\section{Area of flag leaf $=$ Leaf length $\times$ Maximum width $\times 0.74 \ldots($ Bell $\&$ Fischer, 1994)}

\section{Length of the spike $(\mathrm{cm})$}

The length of ten randomly selected spikes from the base to the top was measured. The number of tillers.m ${ }^{-2}$. The number of tillers of the harvested plants in one square meter of each experimental unit was randomly measured.

The number of spike.m ${ }^{-2}$ ripeness (Xavier et al., 2006). Area of flag leaf $(\mathrm{cm})$ from each experimental unit, ten plants were randomly selected where the mean flag leaf area was measured at the end of flowering as in the formula.
The number of spikes in each experimental unit of harvested plants from one square meter was counted. The number of grains.spike ${ }^{-1}$. The number of grains in 30 spikes of the harvested plants in each experimental unit was counted. Spikes were threshed and the total numbers of grains were counted and divided by 30 to fix the number in each spike.

\section{Weight of 1000 grain (g)}

1000 grains of the random samples of total 
Khudur et al ./ Basrah J. Agric. Sci., 32(Spec. Issue 2): 140-155, 2019

yield were counted and weighed from each experimental unit (Kadum et al., 2019).

\section{Grain yield $\left({\left.\mathrm{Kg} . h a^{-1}\right)}^{-1}\right.$}

Grain yield of an area $50 \times 50 \mathrm{~cm}$ from each experimental area was counted after harvest. The harvested spikes were threshed to extract grains. After well cleaned, grains weighted at the basis of $14 \%$ humidity then transferred to Kg.ha ${ }^{-1}$ (Bell \& Fischer, 1994).

\section{Biological yield (Kg.ha-1)}

The total dry weight of grains and the remains of the harvested plants in an area of $50 \times 50 \mathrm{~cm}$ were weighted by a sensitive electric balance, and then the biological yield was estimated.

\section{Yield index $(\%)$}

It is the percentage of grains weight to the weight of vegetative remains (Atiyah \& Whaib, 1989).

$$
\text { H. I. }=\frac{\text { Gy }}{D m} \times 100 \text {. }
$$

H. I. = Harvest index.

Gy $=$ Total grain yield $\left(\mathrm{kg} \cdot \mathrm{ha}^{-1}\right)$.

$\mathrm{Dm}=$ Biological yield $\left(\mathrm{kg} \cdot \mathrm{ha}^{-1}\right)$.

\section{Percentage of protein in grains}

The percentage of protein was counted from the following formula.( Schuffelen et al., 1961)

$$
\% \text { Protein }=\% \mathrm{~N} \times 6.25
$$

\section{Results \& Discussion}

\section{Effect of herbicides on}

the dry weight $(\mathrm{g})$ of

\section{broad-leaved weeds}

Statistical analysis results of table (3) showed significant superiority of cultivar Ebaa-99 in the reduction of broad-leaved weeds weight to $43.64 \mathrm{~g} . \mathrm{m}^{-2}$ in comparison with cultivar Buhooth-22 (46.91 g.m ${ }^{-2}$ ). This may be due to the ability of cultivars to tolerate and compete weeds. The present findings are consistent with previous results by Al-Chalabi \& Al-Akidi (2010) in the superiority of the Ebaa-99 cultivar in reducing the average dry weight of the weeds.

There were significant differences $(p<0.05)$ between the treatments of herbicides and control. However, it was not noticed any significant differences $(p<0.05)$ between the formulation of herbicides. The formula Clodex \& Spotlight spraying treatment recorded the lowest dry weight of broad-leaf weeds of 13.19 g.m ${ }^{-2}$, which was not significantly $(p<0.05)$ that different from the Spotlight and Pallas spraying treatments with an average dry weight of 16.32 and 16.62 g. $\mathrm{m}^{-2}$, respectively. Whereas the control dry weight of broadleaf weeds was $121.26 \mathrm{~g} \cdot \mathrm{m}^{-2}$. The reduction in weeds may be caused by herbicides, which affect the enzyme acetolactate synthase, which helps in the production of Valine, Leucine, and Isoleucine. The amino acids are necessary for cell division because of the stop of weeds growth and dry weight. Therefore, the applications of the herbicides Spotlight and Clodex and Pallas reduced the dry weight of broad-leaf weeds percentages by $89.31,86.73$ and $86.54 \%$ respectively. This results agreed with the results of Asad 
Khudur et al ./ Basrah J. Agric. Sci., 32(Spec. Issue 2): 140-155, 2019

et al. (2017) and Hameed et al. (2019) who mentioned the ability of herbicides to lower the dry weigh of broad-leaved weeds and control it.

Table (3): Effect of interference between cultivars and herbicides on the dry weight of broad-leaved weeds $\left(\mathrm{g} \cdot \mathrm{m}^{-2}\right)$.

\begin{tabular}{llllllll}
\hline Herbicides & \multicolumn{6}{c}{ The dry weight of broad-leaved weeds $\left(\mathrm{g} . \mathrm{m}^{-2}\right)$} & Average \\
\cline { 2 - 7 } Cultivars & Clodex & Spotlight $\begin{array}{c}\text { Spotlight } \\
\& \\
\text { Clodex }\end{array}$ & Pallas & Control Hand & Weeding & cultivars \\
\hline Ebaa-99 & 95.07 & 19.25 & 11.45 & 14.04 & 122.00 & 0.00 & 43.64 \\
\hline Buhooth-22 & 109.40 & 13.39 & 14.93 & 19.20 & 124.53 & 0.00 & 46.91 \\
\hline $\begin{array}{l}\text { Average } \\
\text { herbicides }\end{array}$ & 102.23 & 16.32 & 13.19 & 16.62 & 123.27 & 0.00 & 45.27 \\
\hline \multicolumn{1}{c}{ L.S.D 0.05 } & Cultivars 0.63 & \multicolumn{3}{c}{ Herbicides 1.14 } & Interference1.62 \\
\hline
\end{tabular}

Effect of herbicides on the weight of narrow-leaved weeds

The statistical analysis which represented in the table (4) showed the superiority of spraying weeds with the formulation of Spotlight and Clodex to lower the dry weight of narrow-leaved weeds. This can be due to the action of canceling the AcetylCoA carboxylase enzyme (ACCase) which helps to produce fatty acids in the growing tops and kills the photosynthetic tissues. Similar results were recorded by Anter \& Al-Badr (2012). It also showed that the Pallas herbicide was not clearly affected the weed growth, possibly because of the occurrence of resistance as a result of the frequent use and high concentrations for several years compared to the rest of the herbicides

Table (4): Effect of interference between cultivars and herbicides on the dry weight of narrow-leaved weeds $\left(\mathrm{g} \cdot \mathrm{m}^{-2}\right)$.

\begin{tabular}{|c|c|c|c|c|c|c|c|}
\hline \multirow{2}{*}{$\begin{array}{l}\text { Herbicides } \\
\text { Cultivars }\end{array}$} & \multicolumn{6}{|c|}{ The dry weight of narrow-leaved weeds $\left(\mathrm{g} \cdot \mathrm{m}^{-2}\right)$. } & \multirow[b]{2}{*}{$\begin{array}{l}\text { Average } \\
\text { cultivars }\end{array}$} \\
\hline & Clodex & Spotlight & $\begin{array}{l}\text { Spotlight } \\
\& \\
\text { Clodex }\end{array}$ & Pallas & $\begin{array}{l}\text { Contr } \\
\text { ol }\end{array}$ & $\begin{array}{l}\text { Hand } \\
\text { weeding }\end{array}$ & \\
\hline Ebaa-99 & 2.71 & 22.56 & 2.91 & 6.99 & 35.56 & 0.00 & 14.14 \\
\hline Buhooth-22 & 3.02 & 28.70 & 2.62 & 11.27 & 37.0 & 0.00 & 16.52 \\
\hline $\begin{array}{l}\text { Average } \\
\text { herbicides }\end{array}$ & 2.86 & 25.62 & 2.77 & 9.13 & 36.27 & 0.00 & 15.33 \\
\hline L.S.D & & Cult & s 0.73 & Herb & es 1.16 & Inte & ence 1.65 \\
\hline
\end{tabular}

\section{Effect of treatments on growth and yield components Plant height $(\mathrm{cm})$}

Data of the table (5) showed the length of wheat cultivars treated with difference herbicides at the end of the experiment. Also, the results revealed that the Ebaa-99 cultivar was higher $(77.99 \mathrm{~cm})$ than Buhooth-22 $(76.24 \mathrm{~cm})$. This may be due to the difference in the number of internodes 
and the genetic variations between cultivars (Mollasadeghi et al., 2012). While treatment with the formulation of Spotlight and Clodex had a significant $(p<0.05)$ effect on the height of the plants $(82.90 \mathrm{~cm})$ in comparison with control $(70.01 \mathrm{~cm})$. The reason may be the efficacy of herbicides to reduce the number and weight of weeds, which lead to offer suitable circumstances to crop to get growth supplements like water, light, and nutrients that encourage to increase photosynthesis and other biological activities represented by elongation of internodes and increase the plant height. These results are in accordance with Razzak (2017) who stated that the application of herbicides formulation is better than using a single herbicide.

Table (5): Effect of interference between cultivars and herbicides type on the plant height (cm).

\begin{tabular}{|c|c|c|c|c|c|c|c|}
\hline \multirow{2}{*}{$\begin{array}{l}\text { Herbicides } \\
\text { Cultivars }\end{array}$} & \multicolumn{6}{|c|}{ Plant height $(\mathrm{cm})$} & \multirow[b]{2}{*}{$\begin{array}{l}\text { Average } \\
\text { cultivars }\end{array}$} \\
\hline & Clodex & Spotlight & $\begin{array}{l}\text { Spotlight } \\
\& \\
\text { Clodex }\end{array}$ & Pallas & Control & $\begin{array}{c}\text { Hand } \\
\text { Weeding }\end{array}$ & \\
\hline Ebaa-99 & 78.20 & 73.63 & 85.15 & 82.03 & 72.62 & 84.14 & 77.99 \\
\hline Buhooth-22 & 72.72 & 71.26 & 80.65 & 77.35 & 67.40 & 80.19 & 76.24 \\
\hline $\begin{array}{l}\text { Average } \\
\text { herbicides }\end{array}$ & 75.46 & 72.44 & 82.90 & 79.69 & 70.01 & 82.16 & 77.11 \\
\hline L.S.D 0.05 & & \multicolumn{2}{|c|}{ Cultivars 0.82} & \multicolumn{2}{|c|}{ Herbicides 1.42} & \multicolumn{2}{|c|}{ Interference 2.01} \\
\hline
\end{tabular}

\section{Flag leaf area $\left(\mathrm{cm}^{2}\right)$}

There were significant $(p<0.05)$ differences between the two studied cultivars treated with four different formulas of herbicides in the area of flag leaf (table 6). Ebaa-99 cultivar recorded the highest average Of flag leaf area And was $29.15 \mathrm{~cm}^{2}$ compared to Buhooth-22 $\left(22.18 \mathrm{~cm}^{2}\right)$. The superiority of Ebaa-99 cultivar may be related to the genetic structure or to the long growing time from seeding to flowering which prefers sufficient time for the plant to increase growth and produce more leaf area. The current result is in accordance with Guendouz et al. (2016). The application of herbicides had a significant $(p<0.05)$ effect on the flag leaf area and the treated with the formulation of Spotlight and Clodex showed a significant increase in the average size of the flag leaf area $\left(30.36 \mathrm{~cm}^{2}\right)$ compared to the control treatment $\left(20.59 \mathrm{~cm}^{2}\right)$. This may be related to the effect of herbicides to kill weeds, which give the opportunity to the crop to get benefit from the growing requirements and increasing the rate of photosynthesis. This is consistent with AlHaddad (2015) who used a formulation of 
Khudur et al ./ Basrah J. Agric. Sci., 32(Spec. Issue 2): 140-155, 2019

Table (6): Effect of interference between cultivars and herbicides type on the Flag leaf area $\left(\mathrm{cm}^{2}\right)$.

\begin{tabular}{|c|c|c|c|c|c|c|c|c|}
\hline Herbicides & & & Flag le & $\mathrm{f}$ ar & $\mathrm{ea}\left(\mathrm{cm}^{2}\right.$ & & & Average \\
\hline Cultivars & Clodex & Spotlight & $\begin{array}{r}\text { Spotlight } \\
\text { Clodex }\end{array}$ & $\&$ & Pallas & Control & $\begin{array}{l}\text { Hand } \\
\text { weeding }\end{array}$ & cultivars \\
\hline Ebaa-99 & $\begin{array}{l}28.4 \\
3\end{array}$ & 24.73 & 31.35 & & 30.92 & 27.36 & 32.14 & 29.15 \\
\hline Buhooth-22 & $\begin{array}{l}21.5 \\
2\end{array}$ & 19.08 & 29.37 & & 21.30 & 13.82 & 27.99 & 22.18 \\
\hline $\begin{array}{c}\text { Average } \\
\text { herbicides }\end{array}$ & $\begin{array}{l}24.9 \\
7 \\
\end{array}$ & 21.90 & 30.36 & & 26.11 & 20.59 & 30.06 & 25.66 \\
\hline
\end{tabular}

\begin{tabular}{cccc}
\hline L.S.D 0.05 & Cultivars 0.76 & Herbicides 1.31 & Interference1.86 \\
\hline & & control treatment (521.67). This may belong
\end{tabular}

herbicides and get an increase in the area of flag leaf in comparison with other single herbicide treatments.

\section{Number of spikes. $\mathbf{m}^{-2}$}

Table (7) demonstrated the superiority of cultivar Ebaa-99 in the number of spikes (615.61 spike. $\mathrm{m}^{-2}$ ) in comparison with the cultivar Buhooth-22 (587.17 Spike. $\mathrm{m}^{-2}$ ). This may belong to the ability of cultivars to produce tillers and more spikes. Al-Musa et al. (2012) and Li et al. (2016) refer to the significant differences between cultivars in the number of spikes. $\mathrm{m}^{-2}$. Table (7) also referred to the significant $(p<0.05)$ effect of herbicides application where the formulation of Spotlight \& Clodex causes a significant $(p<0.05)$ increase in the number of spikes.m ${ }^{-2}$ (665.34) in comparison with to the ability of herbicides to decrease the density of weeds and their dry weight, in addition to the increase of tillers number per unit area and an increase in the number of spikes. Bharat et al. (2012) and Shehzad et al. (2012) found that all herbicides had a significant effect on the number of spikes as compared to the control, and formulation of herbicides in particular.

\section{Number of grains.spike ${ }^{-1}$}

Table (8) showed significant $(p<0.05)$ differences in the number of grain/Spike between cultivars where Buhooth-22 had the superiority in this respect (28.66 grain.spike ${ }^{-1}$ ) while Ebaa-99 had 26.18 grain.spike ${ }^{-1}$. This may be related to the alternative compensation between yield components. These results are in accordance with Nizamani et al. (2014).

Table (7): Effect of interference between cultivars and herbicides type on the number of spikes (spikes .m-2).

\begin{tabular}{c|ccccccc}
\hline Herbicides & \multicolumn{6}{c}{ The number of spikes $\left(\right.$ spikes .m $\left.{ }^{-2}\right)}$. & $\begin{array}{c}\text { Average } \\
\text { cultivars }\end{array}$ \\
\cline { 2 - 7 } Cultivars & Clodex & Spotlight & $\begin{array}{l}\text { Spotlight } \\
\& \\
\text { Clodex }\end{array}$ & Pallas Control & $\begin{array}{c}\text { Hand } \\
\text { weeding }\end{array}$ & \\
\hline Ebaa-99 & 573.00 & 556.67 & 680.67 & 672.00 & 532.00 & 679.33 & 615.61 \\
\hline Buhooth-22 & 558.67 & 542.67 & 650.00 & 621.33 & 511.33 & 639.00 & 587.17 \\
\hline $\begin{array}{c}\text { Average } \\
\text { herbicides }\end{array}$ & 565.83 & 549.67 & 665.34 & 646.66 & 521.67 & 659.16 & 601.39 \\
\hline
\end{tabular}


Khudur et al ./ Basrah J. Agric. Sci., 32(Spec. Issue 2): 140-155, 2019

The results presented in the table (8) showed the significant $(p<0.05)$ differences in the number of grains.spike ${ }^{-1}$ with the application of herbicides where the formulation of Spotlight and Clodex had a superiority in this respect (33.03 grain.spike ${ }^{1}$ ) in comparison with the control treatment
(22.89 grain.spike $\left.{ }^{-1}\right)$. The reason may belong to the efficacy of these herbicides to prepare suitable habitat for seeds to grow and develop and increasing photosynthesis without weed competition. This is in coincide with Al-Siaidan (2019).

Table (8): Effect of interference between cultivars and herbicides type on the number of grains (grains .spike ${ }^{-1}$ ).

\begin{tabular}{|c|c|c|c|c|c|c|c|}
\hline \multirow[t]{2}{*}{ Herbicides } & \multicolumn{6}{|c|}{ Control method } & \multirow[b]{2}{*}{$\begin{array}{l}\text { Average } \\
\text { cultivars }\end{array}$} \\
\hline & Clodex & Spotlight & $\begin{array}{l}\text { Spotlight } \\
\& \\
\text { Clodex }\end{array}$ & Pallas & Control & $\begin{array}{c}\text { Hand } \\
\text { weeding }\end{array}$ & \\
\hline Ebaa-99 & 21.28 & 23.42 & 32.61 & 29.88 & 21.42 & 28.46 & 26.18 \\
\hline Buhooth-22 & 28.55 & 25.43 & 33.46 & 31.52 & 24.35 & 28.62 & 28.66 \\
\hline $\begin{array}{c}\text { Average } \\
\text { herbicides }\end{array}$ & 24.91 & 24.43 & 33.03 & 30.70 & 22.89 & 28.54 & 27.42 \\
\hline L.S.D 0.05 & & Cultiv & Irs 1.95 & Herbi & ides 3.38 & Interf & ce 4.78 \\
\hline
\end{tabular}

\section{Length of the spike $(\mathrm{cm})$}

It is clear that there was a significant $(p<0.05)$ difference between cultivars in the length of spike where cultivar Buhooth-22 had a superiority with a spike length of 7.76 $\mathrm{cm}$ while cultivar Ebaa-99 had $6.93 \mathrm{~cm}$ length of the spike (table 9). This may be related to the genetic structure of cultivars.
Al Hadithi et al. (2017) referred to similar results but Jbail \& Falih (2014) referred to reverse results.

The same table revealed the significant $(p<0.05)$ differences between treatments with the application of herbicides where the formulation of spotlight and Clodex recorded the highest average length of the spike $(7.99 \mathrm{~cm})$ in comparison with the control treatment $(6.49 \mathrm{~cm})$.

Table (9): Effect of interference between cultivars and herbicides type on the length of the spike (cm).

\begin{tabular}{|c|c|c|c|c|c|c|c|}
\hline \multirow{2}{*}{$\begin{array}{l}\text { Herbicides } \\
\text { Cultivars }\end{array}$} & \multicolumn{6}{|c|}{$\begin{array}{l}\text { Length of the spike } \\
(\mathrm{cm})\end{array}$} & \multirow{2}{*}{$\begin{array}{l}\text { Average } \\
\text { cultivars }\end{array}$} \\
\hline & Clodex & Spotlight & $\begin{array}{l}\text { Spotlight } \\
\text { \& Clodex }\end{array}$ & Pallas & Control & $\begin{array}{l}\text { Hand } \\
\text { weeding }\end{array}$ & \\
\hline Ebaa-99 & 6.41 & 6.42 & 7.69 & 7.30 & 6.12 & 7.66 & 6.93 \\
\hline Buhooth-22 & 7.02 & 7.91 & 8.29 & 8.51 & 6.86 & 7.96 & 7.76 \\
\hline $\begin{array}{l}\text { Average } \\
\text { herbicides }\end{array}$ & 6.71 & 7.16 & 7.99 & 7.90 & 6.49 & 7.81 & 7.34 \\
\hline L.S.D & & Culti & $\mathrm{rs} 0.57$ & Herb & ides0.98 & Interfe & ence 1.39 \\
\hline
\end{tabular}


This may belong to the ability of herbicides to decrease the density of weeds in the wheat farm to create a suitable habitat for crop growing.

These results were agreed with the results of Nasser-ud-Din et al. (2011) and Al-Hayali et al. (2014) about the effect of herbicide on the length of the spike; however, they not agreed with the study conducted by AlMutrefi et al. (2014), who found no significant differences in all treatments in this respect.

\section{Number of tillers.m ${ }^{-2}$}

The data of the table (10) presented a significant $(p<0.05)$ difference between cultivars in the number of tiller. $\mathrm{m}^{-2}$. The Ebaa-99 cultivar showed superiority in the number of tillers $\left(701.50\right.$ tillers. $\left.\mathrm{m}^{-2}\right)$ compared to Buhooth (683.67 tillers. $\mathrm{m}^{-2}$ ). This may belong to the genetic structure of the cultivars and their ability to take benefit of available growing requirements especially in the absence of weeds due to the activity of herbicides in decreasing the number of these weeds. This is in accordance with the results stated by Al-Yasiri \& Al-Sammak (2015) and Maqbool et al. (2015). Treating with the formulation of herbicides Spotlight and Clodex gave the highest number (754.17 tillers. $\mathrm{m}^{-2}$ ) compared to the control treatment $\left(659.33\right.$ tillers. $\left.\mathrm{m}^{-2}\right)$. This may be caused by the action of herbicides in reducing the number and weight of weeds per unit area where crops get sufficient sunlight and save a high density of branches. This explanation is proved by Anter \& Al-Badr (2012) who found that the weed absence in the field leads to an increase in branches number. The current results also coincided with Kaur \& Aggarwal (2017) and Singh et al. (2019) who found a significant increase in tillers number by the application of herbicides formulation.

Table (10): Effect of interference between cultivars and herbicides type on the number of tillers (tillers. $\mathbf{m}^{-2}$ ).

\begin{tabular}{|c|c|c|c|c|c|c|c|}
\hline \multirow{2}{*}{$\begin{array}{l}\text { Herbicides } \\
\text { Cultivar }\end{array}$} & \multicolumn{6}{|c|}{ Number of tillers (tillers.m ${ }^{-2}$ ) } & \multirow[b]{2}{*}{$\begin{array}{l}\text { Average } \\
\text { cultivars }\end{array}$} \\
\hline & Clodex & Spotlight & $\begin{array}{l}\text { Spotlight } \\
\& \\
\text { Clodex }\end{array}$ & Pallas & Control & $\begin{array}{c}\text { Hand } \\
\text { weeding }\end{array}$ & \\
\hline Ebaa-99 & 659.00 & 662.00 & 766.34 & 733.38 & 633.33 & 754.67 & 701.50 \\
\hline Buhooth-22 & 649.33 & 639.00 & 724.00 & 693.33 & 685.33 & 711.00 & 683.67 \\
\hline $\begin{array}{c}\text { Average } \\
\text { herbicides }\end{array}$ & 654.17 & 650.50 & 745.17 & 713.36 & 659.33 & 732.84 & 692.58 \\
\hline \multicolumn{2}{|c|}{ L.S.D 0.05} & \multicolumn{2}{|c|}{ Cultivars 0.47} & Herbic & cides 1.31 & \multicolumn{2}{|c|}{ Interference1.15 } \\
\hline
\end{tabular}

\section{Weight of 1000 grain $(\mathrm{g})$}

Cultivar Ebaa-99 had a significant $(p<0.05)$ increase in the weight of 1000 grains in comparison with Buhooth-22 where the weight was 43.41 and $31.04 \mathrm{~g}$ respectively
(Table 11). This may be caused by the decrease of grains number in the spikes of cultivar Ebaa-99 which decreases the competition between grains on the photosynthesis products. These results are in accordance with the results of Al-Musa et 
al. (2012) and Jbail \& Falih (2014). The results also recorded a significant $(p<0.05)$ increase in the average weight of 1000 grains on cultivars sprayed by the formulation of Spotlight and Clodex (40.47 g) in comparison with the control treatment $(32.70 \mathrm{~g})$. Application of herbicides especially the formulations for more than one herbicide can kill or discourage weeds growth and grain can make use of the available growth elements to photosynthesize and better growth. This leads to the accumulation of dry matter through the grain fullness stage. Fadoul et al. (2013) and Amare et al. (2014) support this result about the role of herbicides in giving a high weight of 1000 grain.

Table (11): Effect of interference between cultivars and herbicides type on the weight of 1000 grain $(\mathrm{g})$.

\begin{tabular}{|c|c|c|c|c|c|c|c|}
\hline \multirow[b]{2}{*}{$\begin{array}{l}\text { Herbicides } \\
\text { Cultivars }\end{array}$} & \multicolumn{6}{|c|}{ Weight of 1000 grain $(\mathrm{g})$. } & \multirow[b]{2}{*}{$\begin{array}{l}\text { Average } \\
\text { cultivars }\end{array}$} \\
\hline & Clodex & Spotlight & $\begin{array}{l}\text { Spotlight } \\
\& \\
\text { Clodex }\end{array}$ & Pallas & Control & $\begin{array}{c}\text { Hand } \\
\text { weeding }\end{array}$ & \\
\hline Ebaa-99 & 41.78 & 43.66 & 47.05 & 44.93 & 37.44 & 45.62 & 43.41 \\
\hline Buhooth-22 & 28.02 & 28.83 & 33.89 & 35.65 & 27.97 & 31.90 & 31.04 \\
\hline $\begin{array}{c}\text { Average } \\
\text { herbicides }\end{array}$ & 34.90 & 36.24 & 40.47 & 40.29 & 32.70 & 38.76 & 37.22 \\
\hline L.S.D 0.05 & & \multicolumn{2}{|c|}{ Cultivars1.56 } & \multicolumn{2}{|c|}{ Herbicides 2.70} & \multicolumn{2}{|c|}{ Interference 3.82} \\
\hline
\end{tabular}

\section{Grain yield (Kg.ha-1)}

Results in the table (12) indicated a significant $(p<0.05)$ difference in the average grain yield between cultivars. Ebaa99 showed a significant $(p<0.05)$ increase in the average grain yield $\left(5203.34 \mathrm{Kg} \cdot \mathrm{ha}^{-1}\right)$ compared with the Buhooth-22 cultivar of (4459.18 Kg.ha- $\left.{ }^{-1}\right)$. The superiority of Ebaa99 is due to it's surpassed in yield components, the number of spikes. $\mathrm{m}^{-2}$ and weight of 1000 grain which compensates the imperfection in grain number/spike as well as the genetic structure of the cultivars. Mustăţea et al. (2009) support this result. Table (12) is also showed a significant difference in the average yield of grain crops with the application of herbicides. Spotlight and Clodex spray accomplished higher grain yield (5743.66 kg.ha $\left.{ }^{-1}\right)$ compared with control treatment $(3873.33$ kg.ha ${ }^{-1}$ ) due to the absence of weeds

Table (12): Effect of interference between cultivars and herbicides type on the grain yield (Kg.ha-1).

\begin{tabular}{|c|c|c|c|c|c|c|c|}
\hline \multirow{2}{*}{$\begin{array}{l}\text { Herbicides } \\
\text { Cultivars }\end{array}$} & \multicolumn{6}{|c|}{ Grain yield $\left(\mathrm{Kg} \cdot \mathrm{ha}^{-1}\right)$} & \multirow[b]{2}{*}{$\begin{array}{l}\text { Average } \\
\text { cultivars }\end{array}$} \\
\hline & Clodex & Spotlight & $\begin{array}{l}\text { Spotlight } \\
\& \text { Clodex }\end{array}$ & Pallas & Control & $\begin{array}{c}\text { Hand } \\
\text { weeding }\end{array}$ & \\
\hline Ebaa-99 & 4805.07 & 4728.20 & 6739.33 & 5424.53 & 3850.53 & 5672.40 & 5203.34 \\
\hline Buhooth-22 & 4176.93 & 4081.60 & 4748.00 & 4670.27 & 3896.13 & 5182.13 & 4459.18 \\
\hline $\begin{array}{l}\text { Average } \\
\text { herbicides }\end{array}$ & 4491.00 & 4404.90 & 5743.66 & 5047.40 & 3873.33 & 5427.27 & 4831.26 \\
\hline L.S.D 0.05 & & \multicolumn{2}{|c|}{ Cultivars769.71 } & \multicolumn{2}{|c|}{ Herbicides 1333.18} & Interfere & 1885.40 \\
\hline
\end{tabular}


competition. These results are in accordance with Mustari et al. (2014) who stated that treating with herbicides significantly affected the grain yield.

\section{Biological yield (kg.ha-1)}

Results in the table (13) illustrated that cultivar Ebaa-99 had the highest biological yield (15216.85 kg.ha- $\left.{ }^{-1}\right)$ and a significant difference with cultivar Buhooth-22 (12868.34 Kg.ha $\left.{ }^{-1}\right)$. This difference may be related to the genetic structure of the cultivars and difference in height, number of tillers, number of spikes, the weight of 1000 grains, and area of the flag leaf. Al-Musa et al. (2012) found similar results. The data was also showed a significant effect of the application herbicides particularly Spotlight and Clodex formulation on cultivars which achieved $15870.98 \mathrm{Kg} \cdot \mathrm{ha}^{-1}$ compared with control treatment of $11853.53 \mathrm{~kg} \cdot \mathrm{ha}^{-1}$. This superiority may belong to the high flag leaf area, plant high and the number of tillers. This result is in accordance with Chandra et al. (2018) who stated that herbicides application leads to an increase in biological yield.

\section{Table (13): Effect of interference between cultivars and herbicides type on the biological} yield (kg.ha-1).

\begin{tabular}{|c|c|c|c|c|c|c|c|}
\hline \multirow{2}{*}{$\begin{array}{l}\text { Herbicides } \\
\text { Cultivars }\end{array}$} & \multicolumn{6}{|c|}{$\begin{array}{l}\text { Biological } \\
\left(\mathrm{kg} \cdot \mathrm{ha}^{-1}\right)\end{array}$} & \multirow[b]{2}{*}{$\begin{array}{l}\text { Average } \\
\text { cultivars }\end{array}$} \\
\hline & Clodex & Spotlight & $\begin{array}{l}\text { Spotlight } \\
\& \\
\text { Clodex }\end{array}$ & Pallas & Control & $\begin{array}{c}\text { Hand } \\
\text { weeding }\end{array}$ & \\
\hline Ebaa-99 & 14287.47 & 13461.20 & 18325.07 & 14287.47 & 12555.60 & 18384.27 & 15216.85 \\
\hline Buhooth-22 & 12883.20 & 12725.07 & 13416.90 & 13571.20 & 11250.47 & 13363.20 & 12868.34 \\
\hline $\begin{array}{c}\text { Average } \\
\text { herbicides }\end{array}$ & 13585.33 & 13093.13 & 15870.98 & 13929.33 & 11853.03 & 15873.74 & 14042.59 \\
\hline L.S.D 0.05 & & Cultiva & $\operatorname{ars} 402.02$ & Herbic & es 696.31 & Interfer & ce 984.74 \\
\hline
\end{tabular}

\section{Yield index \%.}

Table (14) showed significant differences in the yield index between the cultivars where Ebaa-99 had the highest indicator of $35.25 \%$ while Buhooth-22 recorded only $33.39 \%$. The reason may be due to the genetic structure of the cultivars. Al-Musa et al. (2012) and Jadooa \& Baker (2012) found similar results. It was also clear that there is a significant variation between herbicides applications and control treatment that the formulation of Spotlight and Clodex gets the higher value of harvest indicator (36.12\%) compared to control (32.84\%) This superiority is due to the absence of weeds by the effect of herbicides. Bharat $e t$ al. (2012) and Singh et al. (2015) found similar results. 
Khudur et al ./ Basrah J. Agric. Sci., 32(Spec. Issue 2): 140-155, 2019

Table (14): Effect of interference between cultivars and herbicides type on the yield indicator $(\%)$.

\begin{tabular}{|c|c|c|c|c|c|c|c|}
\hline \multirow[b]{2}{*}{ Cultivars } & \multicolumn{6}{|c|}{ Yield indicator $(\%)$} & \multirow[b]{2}{*}{$\begin{array}{l}\text { Average } \\
\text { cultivars }\end{array}$} \\
\hline & Clodex & Spotlight & $\begin{array}{l}\text { Spotlight } \\
\& \\
\text { Clodex }\end{array}$ & Pallas & Control & $\begin{array}{c}\text { Hand } \\
\text { weeding }\end{array}$ & \\
\hline Ebaa-99 & 33.60 & 35.17 & 36.78 & 37.00 & 30.66 & 38.32 & 35.25 \\
\hline Buhooth-22 & 32.53 & 32.07 & 35.46 & 34.41 & 34.63 & 30.87 & 33.39 \\
\hline $\begin{array}{c}\text { Average } \\
\text { herbicides }\end{array}$ & 33.06 & 33.62 & 36.12 & 36.10 & 32.64 & 34.60 & 34.32 \\
\hline L.S.D 0.05 & & Cult & rs 1.51 & Herb & des 2.48 & Interfer & nce 3.51 \\
\hline
\end{tabular}

\section{Protein percentage $(\%)$}

The results of the table (15) illustrated significant $(p<0.05)$ variations in the protein content in the two cultivars. Buhooth-22 had superiority in the protein content $(10.47 \%)$ as compared with Ebaa-99 (9.91\%). This result can be justified by the reverse relation between protein content and grain yield. Results are supported by and Panozzo et al. (2014) and Dong et al. (2015). Treatment with the formulation of Spotlight and Clodex had no significant effect than Pallas in the protein content of grains, while the lowest percentage of protein content was found with the application of herbicide Clodex alone (Table 15). The reason may belong to the different abilities of herbicides to control weeds in density and dry weight, which gave an opportunity to crop to absorb nutrients and nitrogen, in particular, to produce and store protein in the grains. This result is supported by Souahi et al. (2016) and Pawar et al. (2018) that they found the herbicide application is useful to increase the protein content of grains although there is no significant variation between herbicides in this respect.

Table (15): Effect of interference between cultivars and herbicides type on the protein percentage $(\%)$

\begin{tabular}{|c|c|c|c|c|c|c|c|}
\hline \multirow[t]{2}{*}{ Herbicides } & \multicolumn{6}{|c|}{ Protein percentage $(\%)$} & \multirow[b]{2}{*}{$\begin{array}{l}\text { Average } \\
\text { cultivars }\end{array}$} \\
\hline & Clodex & Spotlight & $\begin{array}{l}\text { Spotlight } \\
\& \\
\text { Clodex }\end{array}$ & Pallas & Control & $\begin{array}{c}\text { Hand } \\
\text { weeding }\end{array}$ & \\
\hline Ebaa-99 & 7.48 & 9.15 & 11.31 & 10.69 & 9.94 & 10.92 & 9.91 \\
\hline Buhooth-22 & 9.36 & 9.66 & 11.50 & 11.38 & 9.60 & 10.98 & 10.47 \\
\hline $\begin{array}{l}\text { Average } \\
\text { Herbicides }\end{array}$ & 8.59 & 9.40 & 11.41 & 11.03 & 9.77 & 10.95 & 15.14 \\
\hline L.S.D 0.05 & & Culti & ars 0.42 & Herk & $\operatorname{des} 0.74$ & Interfe & nce1.04 \\
\hline
\end{tabular}




\section{Conclusion}

The formulation of the herbicides Spotlight \& Clodex was significantly better than other treatments in all crop plant-growing components. Ebaa-99 cultivers record superiority in most of the studied qualities.

\section{Acknowledgments}

We thank the staff of the Department of Plant Protection, Basrah Agricultural Directorate for providing us with herbicides.

\section{Reference}

Al-Chalabi, F.T. (1988). Biological interaction between growth-regulating substances and herbicides in weed control. Ph. D. Thesis, Univ. Wales: 204pp.

Al-Chalabi, F.T. \& Al- Akidi, H.S.M. (2010). Competition of weed and their effects on some growing properties of some wheat cultivars on the accompanied weeds and their effect on the field growth properties. Al-Anbar J. Agric. Sci., 8(4): 444-456. (in Arabic)

Al-Haddad, K.K.K. (2015). Identification and control of weeds growing in the fields of wheat (Triticum aestivum L.) and their effect on the growing yield and protein properties. M. Sc. Thesis. Coll. Agric., Univ. Basrah: 94pp. (in Arabic)

Al-Hadithi, A.A.; Al-Ubaidi, M.O. \& Hadithi, A.G. (2017). Evaluate of introduced genotype of bread wheat (Triticum aestivum L.) in two location western of Iraq. Al-Anbar J. Agric. Sci., 15(Spec. Issue 1): 179-186. (in Arabic)

Al-Hassawy, G.S. \& Al-Jubury, B.A.K. (1982). Weeds and Controlling Methods. Univ. Mosul, Min. High. Educ.: 195pp. (in Arabic)
Al-Hayali, T.A.K.; Salih, S.H. \& Siddiq, M.M. (2014). Effect of some herbicides on the accompanied weeds in wheat fields in the areas of expected rains. Rafidin Agric. J. Sci., 42(1): 146-152. (In Arabic)

Al-Jubury, B.K. (2002). Weed Science. Min.High. Educ. Univ. Baghdad: 320pp. (In Arabic).

Al-Musa, M.A.A.; Ullah, M.A.; Moniruzzaman, M.; Islam, M.S. \& Mukherjee, A. (2012). Effect of BARI wheat varieties on seed germination, growth and yield under Patuakhali District. J. Environ. Sci. Nat. Res.., 5(2): 209-212

Al-Mutrefi, H.I.T.; Lehmood, M.R.H \& AlFartoosi, A.K. (2014). Single and incorporated effect of some chemical herbicides on the control of weeds, growth and yield of wheat. Kerbala Univ. Sci. J., 12(1): 163-172. (In Arabic)

Al-Rawi, K.M. \& Khalaf-Allah A. A. (1980). Design and analysis of agricultural experiments. Dar Al Kuttab Printing and Publishing. Univ. MosulMin. High. Educ. Sci. Res.: 488pp. (In Arabic).

Al-Siaidan, K.J.Y. (2019). Effect of seeding date and low herbicides concentrations on the growth and yield of wheat (Triticum aestivum L.). Al-Muthanna J. Agric. Sci., 7(2): 49-68. (In Arabic).

Al-Sibaee, S.J. (2017). Effect of solarization and some fungi in the control of Leguminous weeds. M. Sc. Thesis, Univ. Basrah: 84pp. (in Arabic).

Al-Yasiri, A.S.M.M. \& Al-Sammak, Q.H. (2015). Effect the Foliar application of potassium in the growth yield five 
Varieties of wheat Triticum aestivum L. J. Kerbala Univ., 13(3): 105-114.

Amare, T.; Sharma, J.J. \& Zewdie, K. (2014). Effect of weed control methods on weeds and wheat (Triticum aestivum L.) yield. World J. Agric. Res., 1(2):124128.

Anter, S.H. \& Al-Badr, S.J. (2012). Effect of cultivation types and chemical herbicides in the growth of wheat (Triticum aestivum L.) and accompanied weeds. Kirkuk J. Agric. Sci., 3(2): 89110. (In Arabic).

Asad, M.; Mahmood, Z.; Rasheed, M.R.A.M.; Ramzan, A. \& Mudassar, M. (2017). Efficacy of some selective herbicides against broad leaved weeds of wheat crop grown under moisture deficit conditions of Pakistan. Turkish J. Weed Sci., 20(2): 38-45.

Atiya, H.J. \& Whaib, K.M. (1989). Understanding Crop Production (Part I). Min. High. Educ. Univ. Baghdad: 1012pp. (In Arabic).

Bell, M.A. \& Fischer, R.A. (1994). Guide to plant and crop sampling: Measurements and observations for agronomic and physiological research in small grain cereals wheat Spec. Report No. 32. Mexico, DF: CIMMYT: 66pp.

Bharat, R.; Kachroo, D.; Sharma, R.; Gupta, M. \& Sharma, A.K. (2012). Effect of different herbicides on weed growth and yield performance of wheat. Indian $\mathrm{J}$. Weed Sci., 44(2): 106-109.

Chandra, S.; Kumar, S.; Acharya, S.; Kumar,P. \& Tyagi, S. (2018). Effect of different weed management practices on growth and yield of wheat and associated weeds. Int. J. Curr. Microbiol. Appl. Sci., 7: 3859-3865.
Ciba-Giegy. ? (1975). Field Trial Manual. Agrochemicals division. Basle: 25pp.

Dong, C.; Shao, L.; Fu, Y.; Wang, M.; Xie, B.; Yu, J. \& Liu, H. (2015). Evaluation of wheat growth, morphological characteristics, biomass yield and quality in Lunar Palace-1, plant factory, green house and field systems. Acta Astronaut., 111: 102-109.

Fadoul, H.E.; El Siddig, M.A. \& El Hussein, A.A. (2013). Assessment of genetic diversity among Sudanese wheat cultivars using RAPD markers. Int. J. Curr. Sci., 6: 51-57.

FAO. (2016). Food and Agriculture Organization of the United Nations Book. Rome Italy. http://www.fao.org/faostat/en/\#data/QC/

Guendouz, A.; Semcheddine, N.; Moumeni, L. \& Hafsi, M. (2016). The effect of supplementary irrigation on leaf area, specie leaf weight, grain yield and water use efficiency in durum wheat (Triticum durum Desf.) cultivars. Ekin. J. Crop Breed. Genet., 2(1): 82-89.

Hameed, Z.; Malik, M.A.; Safdar, A.; Ansar, M.; Shaheen, F.; Ijaz, A. \& Kalim, K. (2019). Comparative efficiency of different post-emergence herbicides for controlling broadleaved weeds in rain-fed wheat. Pak. J. Agric. Res., 32(1): 78-86.

Jbail, W.A. \& Falih, H.F. (2014). Effect of NPK fertilizer on the growth of cultivars of wheat (Triticum aestivum L.). AlMusthanna J. Agric. Sci., 2(2): 1-15. (In Arabic).

Jadooa, K.A \& Baker, H.A. (2012). Effect of seeding depth on the properties of yield and its components of six cultivars 
of wheat. Iraqi J. Agric. Sci., 34(1): 2537. (In Arabic)

Kadum, M.N.; Mutlag, N.A.; Al-Khazal, A.J.; Mohamed, G.A.\& Salman K.A. (2019). Evaluation of the performance of bread wheat genotypes (Triticum aestivum L.) in central region of Iraq by using selection technique. Res. J. Chem. Environ., 23(Spec. Issue 1): 101-105.

Kaur, M. \& Aggarwal, N.K. (2017). Biocontrol potential of Alternaria sp. PMK2, against a devastating weed: Parthenium hysterophorus L. Int. J. Pest Manage., 63(1): 47-53.

Li, Y.; Cui, Z.; Ni, Y.; Zheng, M.; Yang, D.; Jin, M.; Chen, J. ;Wang, Z. \& Yin, Y. (2016). Plant density effect on grain number and weight of two winter wheat cultivars at different spikelet and grain positions. PloS one, 11(5): 1-15.

Maqbool, M.M.; Ali, A.; Haq, T.; Majeed, M.N. \& Lee, D.J. (2015). Response of spring wheat (Triticum aestivum L.) to induced water stress at critical growth stages. Sarhad J. Agric., 31(1): 53-58.

Mollasadeghi, V.; Elyasi, S. \& Mirzamasoumzadeh, B. (2012). Genetic variation of 12 bread wheat genotypes based on number of phonological and morphological traits. Ann. Biol. Res., 3(10): 4734-4740.

Mustari, S.; Bari, M.N.; Islam, M.R. \& Karim, A.S. (2014). Evaluation of selected herbicides on weed control efficiency and yield of wheat. J. Sci. Found., 12(2): 27-33.

Mustăţea, P.; Săulescu, N.N.; Ittu, G.; Păunescu, G.; Voinea, L.; Stere, I. \& Năstase, D. (2009). Grain yield and yield stability of winter wheat cultivars in contrasting weather conditions. Rom. Agric. Res., 26: 1-8.

Naseer-ud-Din, G.M.; Shehzad, M.A. \& Nasrullah, H.M. (2011). Efficacy of various pre and post-emergence herbicides to control weeds in wheat. Pak. J. Agric. Sci., 48(3): 185-190.

Nizamani, G.S.; Tunio, S.; Buriro, U.A. \& Keerio, M.I. (2014). Influence of different seed rates on yield contributing traits in wheat varieties. J. Plant. Sci., 2(5): 232-236.

Öztürk, A.; Bulut, S.; Yildız, N. \& Karaoğlu, M.M. (2012). Effects of organic manures and non- chemical weed control on wheat: I-Plant growth and grain yield. J. Agric. Sci., 18: 9-20.

Panozzo, J.F.; Walker, C.K.; Partington, D.L.; Neumann, N.C.; Tausz, M.; Seneweera, S. \& Fitzgerald, G.J. (2014). Elevated carbon dioxide changes grain protein concentration, composition, and compromises baking quality. A FACE study. J. Cereal Sci., 60(3): 461-470.

Pawar, P.P.; Shendkar, G.S. \& Landge, M.B. (2018). Efficacy of post emergence herbicides (PoE) on growth, yield and quality of late sown wheat (Triticum aestivum L.). Int. J. Chem. Stud., 6(4): 2898-2899.

Razzak, H. (2017). Study of herbicide effect in some wheat (Triticum aestivum L.). properties under Muthanna governorate environment. Al-Muthanna J. Agric. Sci., 5(1): 65-73. (In Arabic).

Schuffelen, A.C.; Muller, A. \& Van Schouwenburg, J.C. (1961). Quick tests for soil and plant analysis used by small laboratories. Neth. J. Agric. Sci., 9(1): 216. 
Shehzad, M.A.; Maqsood, M.; Anwar-ulHaq, M. \& Niaz, A. (2012). Efficacy of various herbicides against weeds in wheat (Triticum aestivum L.). Afr. J. Biotechnol., 11(4): 791-799.

Shewry, P.R.; Halford, N.G.; Belton, P.S. \& Tatham, A.S. (2002). The structure and properties of gluten: an elastic protein from wheat grain. Philos. Trans. R. Soc. Lond. B: Biol. Sci., 357: 133-142.

Singh, M.; Singh, O. \& Singh, R. (2019). Impact of wheat establishment methods and weed management practices on weed flora, yield and nutrient uptake of wheat in rice-wheat cropping system. J. Agric. Res., 6(2): 73-77.

Singh, A.P.; Bhullar, M.S.; Yadav, R. \& Chowdhury, T. (2015). Weed management in zero-till wheat. Indian $\mathrm{J}$. Weed Sci., 47(3): 233-239.

Souahi, H.; Amara, L.M. \& Djebaar, M.R. (2016). Effects of sulfonylurea herbicides on protein content and antioxidants activity in wheat in semiarid region. Int. J. Adv. Eng. Manage. Sci. (IJAEMS), 2(9): 1471-1476.

Steven , Z.K.; Datta, A.; Scott, L. \& Charvat, L.D. (2010). Tolerance of winter wheat (Triticum aestivum L.) to pre-emergence and post-emergence application of saflufenacil. Crop Prot., 29(2):. 148 -152.

Xavier, A.C.; Rudorff, B.F.T.; Moreira, M.A.; Alvarenga, B.S.; Freitas, J.G.D. \& Salomon, M.V. (2006). Hyperspectral field reflectance measurements to estimate wheat grain yield and plant height. Sci. Agric., 63(2): 130-138. 